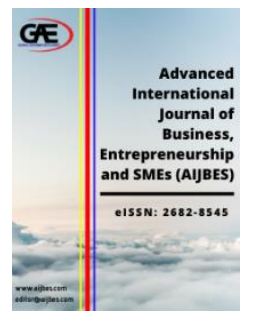

\author{
Advanced International Journal of Business, \\ Entrepreneurship and SMEs (AIJBES) \\ Journal Website: http://aijbes.com/ \\ eISSN: 2682-8545
}

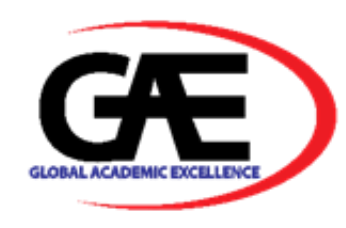

\title{
AN ANALYSIS OF FACTORS THAT CAUSES THE POOR RETENTION IN JAIDON MOTOR SDN BHD
}

\author{
Syafiqah Hanani Mastor ${ }^{*}$, Sabrinah Adam $^{2}$, Beni Widarman Yus Kelana ${ }^{3}$ \\ 1 Azman Hashim International Business School, Universiti Teknologi Malaysia (UTM), Malaysia \\ Email: syafiqahhananimastor@gmail.com \\ 2 Azman Hashim International Business School, Universiti Teknologi Malaysia (UTM), Malaysia \\ Email: sabrinah@utm.my \\ 3 Azman Hashim International Business School, Universiti Teknologi Malaysia (UTM), Malaysia \\ Email: beni@utm.my \\ * $\quad$ Corresponding Author
}

\section{Article Info:}

Article history:

Received date: 31.05 .2020

Revised date: 14.06 .2020

Accepted date: 15.06.2020

Published date: 15.06 .2020

\section{To cite this document:}

Mastor, S. H., Adam, S., \& Kelana, B. W. Y. (2020). An Analysis of Factors that's Cause the Poor Retention in Jaidon Motor Sdn Bhd. Advanced International Journal of Business, Entrepreneurship and SMEs, 2 (4), 12-25.

DOI: 10.35631/AIJBES.24002.

\begin{abstract}
:
The purpose of this action research is to analyse factors that influenced the poor retention of employees in Jaidon Motor Sdn Bhd and recommend as well as implement the best interventions and transformation plan for the issue facing by Jaidon Motor Sdn Bhd. The significance of this research is to increase employee retention and to retain their customer. The methodology used in this study is a mixed-method approach by using a qualitative method followed by a quantitative method. The population of this study consist of all employee of Jaidon Motors Sdn Bhd and the sampling technique is a purposive sampling of 36 participants. Due to the small population, the qualitative method will involve only one participant. The expected findings of factors that influence the poor retention in Jaidon Motor Sdn Bhd will be motivation, employee engagement, compensation, and benefits factor. Hence the suggestion for an intervention plan to revise and add new retention policy of Jaidon Motor Sdn Bhd.
\end{abstract}

Keywords:

Retention, Automotive Repair Industry

\section{Introduction}

Jaidon Motor Sdn Bhd is a family business within the small and medium-sized entrepreneur (SME) sector in Malaysia. They can be classified as an independent automotive repair and maintenance service shop that provides service of repairing and maintenance for automotive. 
It is a family owned business that established in 1976 with the name of Bengkel Jaidon by the founder, Haji Jaidon bin Hanaffi in Kampung Pasir, Tampoi Johor Bahru with financing from MARA. In 1994, Bengkel Jaidon become private limited business entity, Jaidon Motor Sdn Bhd and the following year, 1995, they managed to open another branch in Senai, Kulai Johor and another two branches in 2001 and 2003 at Kluang. It can be estimated that Haji Jaidon provide capital about RM200,000 for each branch.

Currently, they have running four branches of workshop in which in Kampung Pasir, Bandar Baru Uda, Senai, and Pontian. They successfully won tender from local government entity to give service of their official transportation including buses and lorries. Apart from that, Jaidon Motor Sdn Bhd also become official dealer of Hino Motors Sales (M) Sdn Bhd and HyundaiSime Darby Motors Sdn Bhd for Inokom vehicles. The managed to open sales gallery for vehicles of Maxus model, Hino, Inokom and TATA and official dealer of Continental Tires. Therefore, Jaidon Motor Sdn Bhd required their best talents with excellent skills to keep up the expansion and growing of their company. Hence, Jaidon Motor Sdn Bhd have about 50 staff including the owner, top management, administration and mechanics. However, throughout the period at the end of 2017, Jaidon Motor Sdn Bhd decided to close the sales gallery but still maintaining their business as official dealer because of shortage of employee. Consequently, the administration employee in workshop become the salesperson and a key person to contact if any their customer wants the particular vehicles. It is crucial for Jaidon Motor Sdn Bhd to retain their good administration workers and high skill mechanics to keep up their high productivity of operation in the company. Hence the good retention policy played a big part within the company to keep their best talents stay and give the best service to their customer.

In the automotive repair and maintenance industry, Jaidon Motor Sdn Bhd are not the only organization that facing global issue about retaining their best talent in the organization. This significant issue in the organization not only to attract the best talent but also to retain them in order to maintain the highest productivity for maximization of business growth. This high turnover of employee created many disturbances to employer and unnecessary workload to other employee that are left behind in the company (Neog, 2015). As an independent automotive repair and maintenance service shop that provide service of repairing and maintenance for automotive, having a poor employee retention affects their productivity as well as their customer retention. Losing their best talent from time to time gave them big headache as they have to bear the shortage of manpower that affected the business operation as well as the financial sustainability of the organization. Not only that, having a poor retention also will resulted in huge amount of losses incurred in recruiting process of new employee. (Neog, 2015).

Running four branches in different location needs Jaidon Motor Sdn Bhd to hire enough employees to accommodate the operation of all branches. Currently they have 50 workers including administration and mechanics workers in which consist of 4 branches and each branch are not equally adequate worker. Two of the branches had only less than 10 workers in one time including mechanics and administration worker. Another branch only operates with adequate worker in which have highly turnover of administration staff and mechanics that brought problem to the operation and productivity of particular branch. Apart from that, Jaidon Motor Sdn Bhd also facing problem with customer retention in which their customers were not likely to come back if their familiar mechanics were no longer working in particular branch. In terms of administration department, Jaidon Motor Sdn Bhd only required employees to have qualification as low as SPM leaver and Diploma qualification. However, for few years of observation by top management, it can be said that, Jaidon Motor Sdn Bhd always need to open 
new vacancy to hire new administration worker because they were not staying in the company more than one year. For instance, the loss of their employees had caused them inconvenience problem and gradually affects their company productivity as well as caused an unbalanced situation in the internal environment of Jaidon Motor Sdn Bhd. Hence, Jaidon Motor Sdn Bhd worried with the situation that regularly become problem of company and eventually become never-ending problem without any long-term solution will affect the operation and sustainability of Jaidon Motor Sdn Bhd. Thus, they need to understand factors that causes the poor retention of their employees to find better solution for their problem.

\section{Literature Review}

\section{Employee Retention}

Employee retention as a term were often used since 1970s in human resource management. By using the statement of as long as economy condition allowed the employer to employ the employee, employee must work with them and deliver their best work as a basis of good relationship between employer with employee in the organization (Adrea Lewis, 2012). Employee retention can be classified as a process of retaining the employee whereby employer putting effort to ensure employee to stay in organization for a longer period or until any particular project ends by motivate and encourage them to stay (Neog, 2015). Prior study mentioned that, employee retention benefit organization because employee that stays in organization are valuable asset for company as they hold a lot of company's secrets and become the source of knowledge. Studies of Kishore et. al (2014) acknowledged that commitment of employer in the organization play crucial part to ensure employee have less intention to exit from organization. The same study also found that, due to poor retention of employee, it has strongly related with direct cost that organization needs to bear due to interruptions of productivity and loss of skills and knowledge that associated with employee.

Using the equity theory of motivation by Adam (1965), employee retention can be influenced by the motivation of employee. In order to motivate the employee to commit more in organization, justice and fairness in compensation and promotion plays big part in the motivation (Odour et al, 2016). The main concern of employee is the output rewards that did not reflect with their input job in which they felt unfairness towards the organization. The mismatch between job input and output rewards cased the bad perspective of employee and triggered them to leave organization.

A study by Chat-Uthai, M. (2013) concluded that employee retention are positively correlated with employee wellbeing, their values and their potential career developments within the organization. he also mentioned that another strong reason that influenced the poor retention of employee was engagement from their employer. If the organization give a positive engagement towards their employee, employee will feel emotionally and intelligently bond with organization and can motivate them to put more of their passion into their job. However, same study shown that, the disengage employee are highly risk to leave the organization because of low job satisfaction resulted from been neglected by organization. Hence, it is important factor that organization needs to highlight in order to fix their poor retention employee. 


\section{THE AUTOMOTIVE ECOSYSTEM}

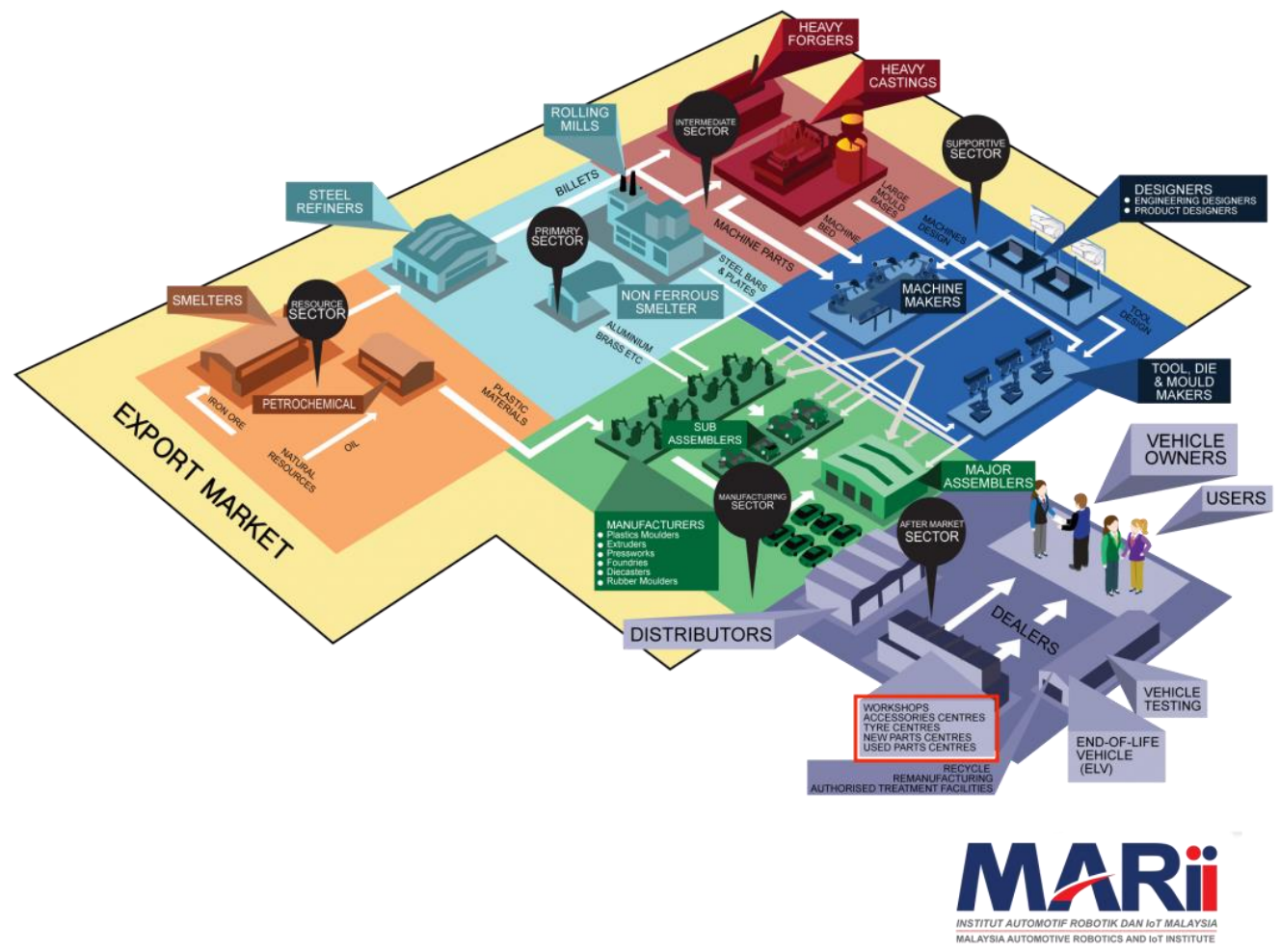

Figure 1: The Automotive Ecosystem

Source: Malaysian Automotive Robotics and IoT Institute

In the automotive industry ecosystem, automotive repair and maintenance industry placed in after market sector according to MARii (Figure 1). Globally, automotive industry was estimated to growth in 2026 by USD 810.30 billion due to the several factors and one of contributor are from repair and maintenance industry because of the rise of customer preference in using locally owned repair workshop. Another reason is an increase of passengers safety awareness that play crucial role in the growth of automotive industry. Apart from that, due to technological advancement and changes, automotive industry within Asia-Pacific Region also estimated to growth because of huge consumption of vehicle for daily use. Hence automotive repair and maintenance industry also will be affected due to increase demand by customer. Thus, workforce in that particular industry should prepare with skills and knowledge to supply their services for demanded customers. By doing so, organization must keep their heads forward by thinking the perfect retention strategy for their best employee to stay in organization.

Study in Ghana concluded that, one of factor that influenced the poor retention among workforce in automotive and repair industry was the failure to adapt new technology advancement in organization. That study found that, organization culture, engagement and commitment were the barriers for employee to stay in organization (Anlesinya, A., 2018). Organization support and encouragement for employee in training program are important as they can motivate employee to stay in organization regardless of any factor besides technology 
advancement. When organization failed to do so, employee become less motivated and decided to quit from organization.

In Malaysia context, automotive maintenance and repair industry contribute around $4 \%$ in country GDP growth (MARii.com.my). One factor that increase the demand of this industry is the upsurge of customer consumption of vehicle year by year and the rise of average age of vehicle due to technological advancement. This implied that the workforce for this industry are much-needed to growth as many as reported in MARii as at 2018 was over 53,000 workforces. This give clear alarm to SMEs and giant organization in Malaysia to retain their best employee to stay in organization in order to supply sufficient service to market demand.

\section{Relevant Model}

\section{Human Capital Theory}

Study of technical report from Ulster University Business School, they defined human capital theory is the individual stage as physical resources to the organization by contributing not only theirs skill and expertise but also their creativity, innovation as well as changes that can help the organization to meet their objectives (McCraken et al, 2017). They also mentioned that, the basis of human capital theory is strongly relative with employee wellbeing including their development and motivation. Rather than focusing on organizational result, this theory more narrowed to the job performance and productivity of employee. According to Buta (2015), human capital can be structured from several aspects and features in which included an education from young age until professional training, work experience and the health state of individual. Different company have different perspective of human capital and mostly it related with resource of work force. Usually organization used human capital in order to sustain their stability of organization in the market. Hence it is important for them to maintain competitive advantage.

Becker mentioned that human capital as the most biodegradable and sustainable capital. Previous study has shown, human capital can be defined as an investment made by organization for employee in their training and education in order to increase their knowledge and skill as well as expertise that can benefit organization in terms of productivity maximization (Becker, 1993: Khasawneh, 2011). Training that have been mentioned also can be categorized into two category which are general training and specific training. Both have different features whereby knowledge that employee can get from general training can be transferable to another organization or in simple words, knowledge that needed in all organization. another category is specific training in which can only benefited to particular of organization (Brush and Ruse, 2005: Khasawneh, 2011). It can be concluded from that study, by using human capital planning organization can enjoy the benefit in which result from effective employee management and investment or action decision efficiency that in line with organization strategy and objectives.

Study found that, there are several features of human capital that needs to be focused on. The first feature contribute big portion to the growth of organization is innovative and creativity thinking of employee same important as the second features of knowledge and skills of employee. by encouraging employee to think out of box and give them opportunity to voice out their suggestions regardless of their position can create creative and innovative environment that can contribute to the growth of organization. 


\section{Motivation Theory from Maslow's Hierarchy of Needs and Herzberg's Two Factors}

Maslow's Hierarchy

of Needs

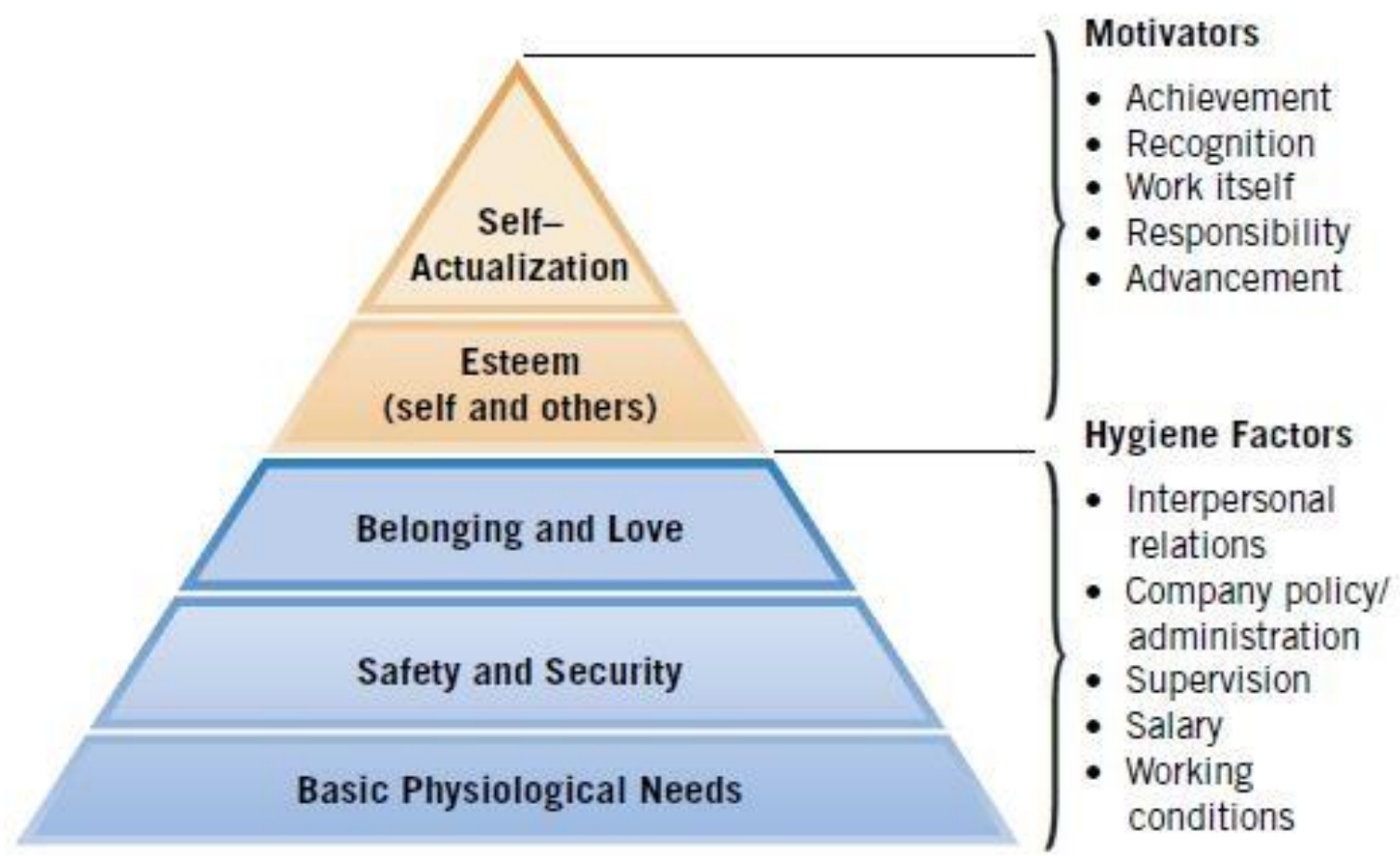

Herzberg's

Two Factors

Figure 2: Maslow's Hierarchy of Needs and Herzberg's Two-Factor Theory

Managing organization in competitive environment make organization to aware of factors that play big role in influencing their competitive advantage. One of important role in organisation is employee that being the backbone of organization. Without the employee, the operation of organization cannot run and would affects the productivity and sustainability of the business. Hence by retaining good employee into organization can make the future of organization brighter and essentially can reach the objective of organization. Study shown that, relationship between job satisfaction of employee and job performance were positively correlated (Judge et al, 2001) and satisfaction also can affect the tendency of fluctuation and absenteeism of employee within the organization (Fried et al 2008; Farrell \& Stamm 1988). Therefore, the major motivation of this study is adopted from Maslow's Hierarchy of Needs and Herzberg's Two-Factor Theory (Figure 2).

Theory of motivation has been a highlighted in management study in the past until now. Based on above Figure 2, Abraham Maslow (1908-1970) established a hierarchy of needs that can be satisfied through level order. He classified human needs into five categories of level that have hierarchy. Human needs meet the higher level if they successfully fulfilled the lower level of needs. The bottom level of hierarchy can be called as physiological needs in which human needs basic things in order to survive such as foods, clothing, shelter and sex. Without these things, human cannot survive. The next level is safety needs whereby the job security, safe working conditions and compensation and benefits is important to satisfy human needs. Third level can be classified asocial needs of belonging and love. Fourth level is the self-esteem needs of human in which human are seek recognition of their competence and also their confidence towards oneself. Lastly the highest level of hierarchy is self-actualization (Maslow,1943: 
Boerner, L., 2015). Therefore, high motivation of employee will reach when all level of hierarchy's was satisfied by human needs. To sum up, these conditions must be applied in real life basis of work and the job also must be meaningful and motivating for employee.

Apart from that, study by Frederick Herzberg (1923-2000) broaden the idea of motivation by Maslow (Boerner, 2015). He specifically questioning what employee needs to motivate them. From his findings, then he established Herzberg's Two-Factors theory that indicates differences between job satisfaction and dissatisfaction. According to him, trigger factor that lead to job satisfaction of employee are achievement, recognition, work itself, opportunity of promotion and responsibility. These factors if present for them can boost their motivation to stay in company. However, Herzberg also mentioned that, other factor that if absent can cause dissatisfaction of employee such as salary, working conditions and supervision can be classified as hygiene factor but if present, it does not trigger extra satisfaction for employee.

Both approaches of human motivation have several similarities in which they focus on human needs of compensation in terms of money cannot be the single factor of human motivation in individual level. Study also found that in both theories, they highlighted more on recognition and responsibility that lie within the hierarchy and model (Maslow,1943: Herzberg 1959: Boerner, 2015). Besides the similarities, the differences between both theories is employer can get the full understanding of overall motivation of employee by using hierarchy rather than using the two-theory mode, employer can expect the implication of it.

To sum up, employers should consider both theory to shape and structure the workplace that can motivate employee by comprehensively understand the implication of factors that can trigger employee to keep motivated in doing their job. In doing so, employer also should keep in mind that money not the only driver to motivation employee but many other factors that play big influence on them.

\section{Intervention Plan}
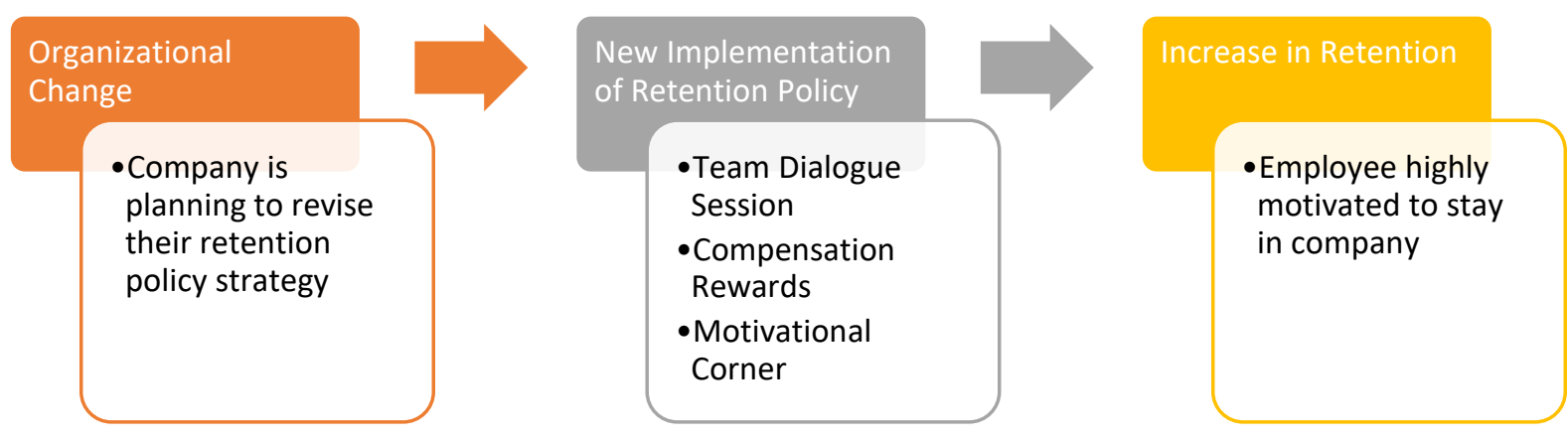

Figure 3: Intervention Plan

For this action research, researcher recommend intervention plan as above Figure 3, for Jaidon Motor Sdn Bhd by changing the organization level in which revise and implement new retention strategies into their employee retention policy. Based on previous study indicated at previous section, it can conclude that, Jaidon Motor Sdn Bhd needs to focus on motivation factor of their employee and putting into consideration to make it as basis of their new retention 
policy. By doing so, several new retention policies will be implemented into Jaidon Motor Sdn Bhd as follows: -

\section{Team Dialogue}

When discussed about motivation of employee, one that play a big part is employee engagement and one of component of employee engagement is team dialogue session. A study by Seymour, Michael \& Geldenhuys, Dirk (2018). Team dialogues will be conducted every two weeks on Sunday before the operations begun. During dialogue session, employer will give briefing the progress of projects and employee also needs to update their work progress. Therefore, during this session also, employee will be given opportunity to voice out their concern or opinions, suggestions or recommendations to their employee. The implementation of open-door policy by Jaidon Motor Sdn Bhd encourage employee within the organization to share their ideas, creative and innovate thinking that can benefit organization. hence, employee will feel motivated when employer acknowledge their concern and lower their intention to resign.

\section{Motivational Corner}

From Human Resource Management (HRM) view on human, they indicate that human or people are more satisfy with their jobs when they are motivated by interrelated factors of money, need for affiliation and desire for meaningful work in their organization (Zin, 2012). Hence, motivation is one of the keys that can be the reason of employee to stay in an organisation. Therefore, Jaidon Motor Sdn Bhd will establish motivational corner that will be updated every week by administration employee and top management. Motivational corner consists of bulletin board that will be posted with motivational quote and updated every week. Even though this might be as a little effort from employer, but employee will appreciate the effort and make it as a culture to motivate of each other. The bulletin board also will be posted the recognition of employee that shown the highest sales during the whole month. The implication of this action to increase the motivation of employee to feel appreciated by Jaidon Motor Sdn Bhd as well as to make them stay in organization.

\section{Compensation Rewards}

A company had done tremendously in retaining their employee by using performance driven rewards by giving their employee rewards in monetary form based on their work performance (Sandhya, 2011). This kind of policy make the employee stays in organization longer than before and have hesitation to exit from organization without strong reason. Hence by implementing this could also help Jaidon Motor Sdn Bhd to retain their employee and avoid exiting from organisation easily. Therefore, all branches of Jaidon Motor Sdn Bhd are mandatory to implement compensation rewards based on performance review. The compensation rewards will be done in fair manners in which favoritism and injustice must be avoided. Performance review will be conducted monthly and the compensation rewards will be given following month depends on the economic conditions of Jaidon Motor Sdn Bhd. The implication of this retention policy to make employee feel recognized of their inputs efforts to deliver the best output for organization.

\section{Methods}

\section{Action Research Process Design}

Organizational Development model of Action Research adoption from System Model of the Action Research Process (Lewin, 1958). 
Input

Transformation

Output

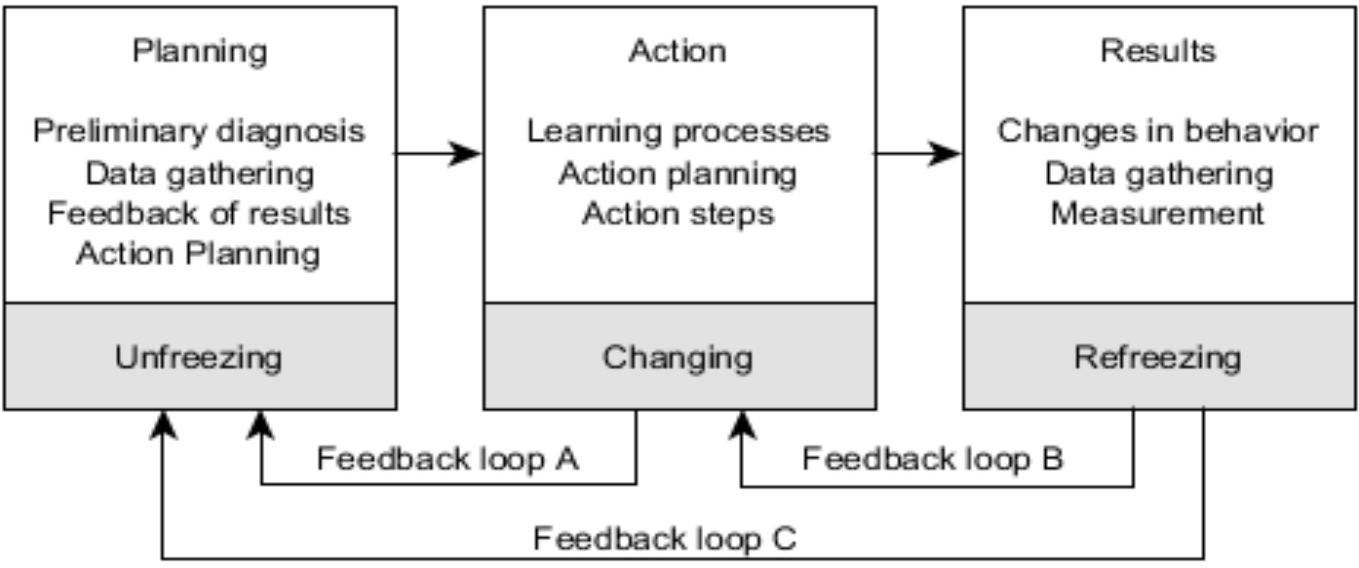

Figure 4: Action Research for Organizational Development Model Source: Lewin, 1958.

According to Lewin (1958) as cited in Kwong et al. (2016) most of interventions through organization development OD are using action research process as a model. They describe the action research is a process whereby the systematically collecting research data regarding the ongoing system in line with some objective, goal or that system, feeding these data back into system, taking actions by carefully identify selected variables within the system based on both data and on hypothesis and provided the evaluating the results of action taken by collecting more data. Kurt Lewin mentioned that the OD's underlying philosophy are concerned to social change that related to an efficient and permanent social change. He believed that the changes of social change are particularly relates to action. Hence each of action taken was carefully includes a spiral of steps and each of which composed of a circle of planning, action and factfinding about the result of action. His description of the process of change involves three steps and it can be summaries the steps and processes involved through action research as above figure.

Firstly, the cycle begins with planning action started by the clients and consultants work together. In the course of the first stage, it focusses more on the key elements of the case involving the preliminary diagnosis of the problem, gathering data information related to the problem, getting the feedback outcomes from stakeholders involved with the problem and lastly to initiate an action planning of for solution. This basically can be classified as input phase for client in which they acknowledge the problem occurrence within company but does not realize that they need outside helps to effect changes and opinions. This kind of stage also called unfreezing stage in which clients faced dilemma and disconfirmation as well as acknowledge of need to change reflects to their problem.

The second stage can be known as action or transformation phase. This changing phase is whereby the situation had been diagnosed and the new model of behaviour are explored and tested by both parties. The learning processes as well as planning and executing the new behavioural model into client were includes in this stage. The feedback gathered from the execution of changes would move via Feedback Loop A in which would effect of changing the previous planning to bring the learning activities of client system into better alignment with 
change objectives. This stage also includes action-planning workshop and activity carried by both party of their system as a part of transformation stage.

The third stage which is the last stage of action research is the results phase or output of this process. Taken from corrective action of previous phase, this stage includes the actual changes in behaviour resulting from second stage. Again, in this stage, the process of gathered data gain from client system so that the progress can be determined, and adjustment can be made. Based on Feedback Loop B, the minor adjustments of this nature can be made in learning activities as above figure. This stage also called as refreezing whereby the application of new behaviour is evaluated, and if reinforcing and adopted.

Overall, for this action research, me as an external consultant initiate all stages with Jaidon Motor Sdn Bhd. This includes input phase, transformation phase and output phase as well as all the feedback loop from A to C. The preliminary diagnosis of the problem case happen in Jaidon Motor Sdn Bhd in the first stage are important to know all relevant collection data are intercorrelated with one another or not. By doing so, it came to conclusion of planning action that will be taken and tested how well the interventions plan works. Jaidon Motor Sdn Bhd can rely on this model with systematic steps in order to know the roots of problem and the good as long as long term solution to their problem.

\section{Philosophy of Research - The Pragmatic Worldview}

Creswell (2009) stated that the philosophy behind mixed method approach is pragmatism in which causes by actions, situations and consequences. It is focusing more on the understanding of research problem rather than method. Among of philosophical basis for research in Pragmatism is they have freedom of choices in methods, techniques, procedures that meets their needs and researcher have an opportunity to explore multiple methods in collecting data information and analysis in different forms with different assumption as well as in different worldviews. Hence, by using this method the author has freedom in collecting data in Jaidon Motor Sdn Bhd that best meet her needs and purposes.

\section{Mixed Method Approach}

Mixed methods are a research approach whereby researchers collect and analyse both quantitative and qualitative data within the same study (Creswell, 2011). Mixed methods research draws on potential strengths of both qualitative and quantitative methods, allowing researchers to explore diverse perspectives and uncover relationships that exist between the intricate layers of our multifaceted research questions. Mixed methods research requires a purposeful mixing of methods in data collection, data analysis and interpretation of the evidence. The key word is 'mixed', as an essential step in the mixed methods approach is data linkage, or integration at an appropriate stage in the research process (Creswell, 2014). Purposeful data integration enables researchers to seek a more panoramic view of their research landscape, viewing phenomena from different viewpoints and through diverse research lenses.

\section{Time Horizon}

Time horizons is needed to determine the specific time frame to do the research (Saunders et al, 2009). This study will use cross sectional time horizons in which requires only short time frame only. He also mentioned that cross sectional always used as survey strategy.

\section{Unit of Analysis}

In this research, the unit of analysis is employees of Jaidon Motor Sdn Bhd which consist of 50 employees including owners and top management. In Jaidon Motor Sdn Bhd HQ consist of 
three level hierarchy but in other branch consist of two-level hierarchy. Usually in Jaidon Motor Sdn Bhd hierarchy includes top management, administration and mechanics except in headquarter, there is another level called middle managers. However, researcher focused on purposive sampling and using homogenous sampling in which administration employee and mechanics from both departments which consist of 36 employees. Hence for the pilot study, this study will take four persons from the sample size of 36 to do the pilot survey but this four sample will be not included in final study. Thus, this study will use the rest of sample for pre survey before the implementation of intervention plan and also using the same sample size for post implementation survey using the same questionnaire.

\section{Sampling Technique}

This study using mixed method approach thus, purposively sampling was used as a technique as it more suitable for this research. The sampling will be focus on employee with position of administration and mechanics only. Creswell (2009) mentioned that, purposive sampling is more useful for qualitative method because the participant is more experienced of theme but in this case, purposive technique will be used for both methods.

\section{Research Instrument}

Instrument of research is crucial for this study in order to collect the accurate and sufficient data. Hence, this study use interview questions and survey questions that have been adopt and adapt form previous study. The interview questions consist of 10 questions that reflected from the research questions and have been modify from previous researcher. 10 questions that have been covered the eight sections of variable and all the questions have an open-ended question which participant needs to explain their answer. The questionnaires will be distributed using Google Survey platform, this study using rating questions to conduct the concept and variables of research. Hence study use 5 Likert-style rating scale of $1-5$ with starting of (1) strongly agree, (2) agree, (3) neither agree or disagree, (4) disagree and (5) strongly disagree. The questionnaires consist of nine sections and each section consist of five questions each. The first sections, section (A) will be focus on the poor retention of employee in order to measure the effects of poor retention of employee towards other employee. Secondly, section (B) will be focused on the intention of employee to resign from the company in the basis of ethics or value of organization, recognition and outside opportunities. In sections (C), study will measure their opportunities in career advancement in which the training program provided by company for them. Next is sections (D) in which measuring the motivation factor are most likely influence the employee to stay in company. Furthermore, sections (E) and (F) are measuring the communication and relationship between managers with their employee followed by the organization support received by employee and the remunerations and befits that provided by company for employee. All these factors are measure thoroughly before the implementation of intervention plan and will be measured again after the implementation of interventions.

\section{Validity}

In mixed method study, it is important to check the validity and reliability of both qualitative and quantitative data in terms of accuracy and transparency of it. Validity can be defined as the accuracy of data collection and focusing on qualitative method of study. it must follow some measures unlike reliability, it must be consistent with other previous study that have different context (Creswell, 2009). According to Creswell (2009) also mentioned that, researcher needs to use several validity strategies to prove the ability of researchers to assess the accuracy of the data collection. This includes thick and rich description strategies on theme of study. In the interview session, participant will be brief regarding the theme and they allow to share their experiences freely without any restrictions or barrier in their perspectives. 
Apart from that, this study has been gone through content validation for items in questionnaire and items in interview questions by two academic expert and two practitioners. Below is the profile of person that validate the content of this study.

Table 1: Content Validator Profile

\begin{tabular}{ccc}
\hline Name & Position & Unit of Expert \\
\hline Suraya Hamimi Binti & $\begin{array}{c}\text { Senior Lecturer, Coordinator of } \\
\text { Mastor }\end{array}$ & $\begin{array}{c}\text { Human Resource } \\
\text { Management }\end{array}$ \\
& UiTM Melaka Branch, Melaka & \\
City Campus & Senior Lecturer, & Smart Digital Community \\
$\begin{array}{c}\text { Dr Beni Widarman Bin } \\
\text { Yus Kelana }\end{array}$ & AHIBS UTM & HR Practitioner with 5 years \\
Nurnadia Binti Zulkifli & HR Executives & experiences \\
Ezatul Hasanah Binti & Administrations Executives & Administrations with 6 years \\
Jaidon & & experiences
\end{tabular}

\section{Reliability}

Reliability can be defined as whether the data collection technique and analysis similar with the findings by evaluate results and transparency with previous study in other occasions (Saunders et al, 2009). Study shown that reliability cannot run from the threat itself such as error and biasness from the subject or participant as well as threat of observation error and bias (Robson, 2002). This study facing the participant error and bias throughout the period of research. However, it can overcome the threat by providing the solution that perfectly fit for participant. In this study, to study the effects that causes the poor retention, participant will be assess the questionnaire on Sunday, the beginning of week before they start their operation.

\section{Data Collection}

50 questionnaires will be distributed to the respondents and it will be the primary data sources. Data collection for RQ1 will be used mixed approach by structured interview and structured questionnaires survey as well as for RQ2. For the qualitative method, the interview session will be conducted to the participants at Jaidon Motor until the data saturated.

\section{Data Analysis}

The data analysis for qualitative method will be using manual transcription and for quantitative method will be using SPSS. SPSS is an integrated interface to run inputs such as advanced statistics, regression and description statistics and the output of this statistics will be a comprehensive tables, charts and decisions trees in just one tool (Pallant, 2007). Table 2 shows the approach and data analysis to every research question.

Table 2. Research Question with Approach

\begin{tabular}{cccc}
\hline & Research Question & Approach & SPP \\
\hline RQ1 & $\begin{array}{c}\text { What elements that contributes the } \\
\text { poor retention in Jaidon Motor Sdn } \\
\text { Bhd? }\end{array}$ & $\begin{array}{c}\text { Qualitative Method - } \\
\text { Interview }\end{array}$ & Miles and \\
RQ2 & $\begin{array}{c}\text { How retention strategies can } \\
\text { influence the turnover in Jaidon } \\
\text { Motor Sdn Bhd? }\end{array}$ & $\begin{array}{c}\text { Quantitative Method - } \\
\text { Questionnaires }\end{array}$ & $\begin{array}{c}\text { Technique, } \\
\text { SPSS }\end{array}$ \\
& & \\
\hline
\end{tabular}




\section{Conclusion}

From the literature review of previous study of retention, several factor that influenced retention employee in organization which are motivation, well-being, and engagement with organization. Furthermore, it was reported within the automotive repair and maintenance industry, the retaining employee become crucial in globally to supply the best service sector to the customer due to growth of market demand and technology advancement. Hence without the engagement from organization itself to support their employee, their motivation factor effects, and they would like to leave the company. Therefore, two model of theory that relevant to the case has been discussed thoroughly whereby human capital theory explained that, human can be valuable asset to organization and back bone of organization to reach their objective and goals. By doing so, motivation factor was the trigger factor that can ensure good employee to stay in organization. This can be supported with previous study of Maslow's Hierarchy of Needs and Herzberg's Two-Factor Theory. To sum up, this study suggested intervention and transformation plan that can be the solution of poor retention in Jaidon Motor Sdn Bhd. The expected findings of this research will be the increase in employee retention and turnover decrease by revising Jaidon Motor Sdn Bhd retention policy.

\section{References}

Abdul Wahab, Muhamad \& Mohd Jawi, Zulhaidi \& Abdul Hamid, Iskandar \& Solah, Mohd Syazwan \& Latif, M. \& Md Isa, Mohd Hafzi \& bin Abdul Khalid, Muhamad Syukri \& Ariffin, Aqbal Hafeez \& Hamzah, Azhar. (2017). Automotive Consumerism in Malaysia with Regard to Car Maintenance. Journal of the Society of Automotive Engineers Malaysia. 1. 137-153.

Anlesinya, A. (2018), "Organizational barriers to employee training and learning: evidence from the automotive sector", Development and Learning in Organizations, Vol. 32 No. 3, pp. 8-10. https://doi.org/10.1108/DLO-03-2017-0022

Arokiasamy, A. R. A., \& Park, J. (2018). Factors Affecting Job Satisfaction in the Malaysian Automotive Industry. Sumerianz Journal of Business Management and Marketing, $1(2), 63-72$.

Boerner, L. (2015). Maslow's Hierarchy of Needs and Herzberg's Two-Factor Theory: Similarities, Differences and Implications for Modern Management

Chat-uthai, M. (2013). Leveraging Employee Engagement Surveys Using the Turnover Stimulator Approach: A Case Study of Automotive Enterprises in Thailand.

Creswell, J. W., \& Plano Clark, V. L. (2011). Designing and conducting mixed methods research (2nd ed.). Thousand Oaks, CA: Sage.

Creswell, J. W. (2014). Research Design: Qualitative, Quantitative and Mixed Methods Approaches (4th ed.). Thousand Oaks, CA: Sage.

Data, R. and. (2019, March 27). Automotive Repair \& Maintenance Service Market Is Estimated To Reach USD 810.30 Billion By 2026: Reports And Data. Retrieved from https://www.globenewswire.com/newsrelease/2019/03/27/1774167/0/en/AutomotivR epair-Maintenance-Service-Market-Is-Estimated-To-Reach-USD-810-30-Billion-By2026-Reports-And-Data.html.

De Prins, P., Stuer, D., \& Gielens, T. (2018). Revitalizing social dialogue in the workplace: the impact of a cooperative industrial relations climate and sustainable HR practices on reducing employee harm. The International Journal of Human Resource Management, 1-21. doi:10.1080/09585192.2017.1423098

French, Wendell and Bell Cecil (1995). Organization Development, Englewood Cliffs, Simon \& Schuster p. 138 
Islam, Mohammad \& Alam, Jahangir. (2014). Factors influencing Intention to Quit or Stay in Jobs: An Empirical Study on selected sectors in Bangladesh. Stamford Journal of Business Studies. 6. 142-165.

Kaptein, M., \& Van Tulder, R. (2003). Toward Effective Stakeholder Dialogue. Business and Society Review, 108(2), 203-224. doi:10.1111/1467-8594.00161

Kishore, Morthati \& Arun Kumar, Dr. A. \& Shekhar, V. (2014). A Study On Employee Retention Practices In Pharmaceutical Companies Of Northern Telangana. 1.

Khasawneh, S. (2011), "Human capital planning in higher education institutions: A strategic human resource development initiative in Jordan", International Journal of Educational Management, Vol. 25 No. 6, pp. 534-544. https://doi.org/10.1108/09513541111159040

Kurt Lewin (1958). Group Decision and Social Change. New York: Holt, Rinehart and Winston. p. 201.

M. McCraken, R. Mclvor, R. Treacy, T. Wall. (2017). Human Capital Theory: Assessing The Evidence For The Value And Importance Of People To Organizational Success.

Mason, E. C. M., \& McMahon, H. G. (2009). Supporting Academic Improvement among Eighth Graders at Risk for Retention: An Action Research Intervention. RMLE Online, 33(1), 1-5. doi:10.1080/19404476.2009.11462064

Neog, B.B., \& Barua, M. (2015). Factors Affecting Employee's Retention in Automobile Service Workshops of Assam: An Empirical Study.

Sadangharn, P., \& Joungtrakul, J. (2018). Retention of old-aged human capital in the Thai automotive industry. International Journal of Learning and Intellectual Capital, 15(1), 65-82. https://doi.org/10.1504/IJLIC.2018.088349

Palinkas, L. A., Horwitz, S. M., Green, C. A., Wisdom, J. P., Duan, N., \& Hoagwood, K. (2013). Purposeful Sampling for Qualitative Data Collection and Analysis in Mixed Method Implementation Research. Administration and Policy in Mental Health and Mental Health Services Research, 42(5), 533-544. doi:10.1007/s10488-013-0528-y

Pallant, J. (2007). SPSS survival manual: A step by step guide to data analysis using SPSS for windows (3rd ed.). England: McGraw Hill Open University Press Milton Keynes, UK.

Pasban, M., \& Nojedeh, S. H. (2016). A Review of the Role of Human Capital in the Organization. Procedia - Social and Behavioral Sciences, 230, 249-253. dodoi: 10.1016/j. sbspro016.09.032

Plano Clark, V. L., \& Creswell, J. W. (2015). Understanding Research: A Consumer's Guide. Upper Saddle River, NJ: Pearson.

Sandhya, K., \& Kumar, D. P. (2011). Employee retention by motivation. Indian Journal of science and technology, 4(12), 1778-1782.

Saunders, M., Lewis, P. and Thornhill, A. (2009) Research Methods for Business Students. Pearson, New York.

Seymour, Michael \& Geldenhuys, Dirk. (2018). The impact of team dialogue sessions on employee engagement in an information and communication technology company. SA Journal of Human Resource Management. 16. 10.4102/sajhrm. v16i0.987.

Tan, E. (2014). Human Capital Theory. Review of Educational Research, 84(3), 411-445. doi:10.3102/0034654314532696

The Automotive Industry (2017). Archived from the original on 19 October 2019.

The Aftermarket Sector. (n.d.). Retrieved from http://marii.my/the-aftermarket-sector/.

Zin, S.M., Ahmad, N., Ngah, N.E., Ismail, R., Ibrahim, N., Abdullah, I., \& Tajuddin, N.H. (2012). Motivation Model for Employee Retention: Applicability to HRM Practices in Malaysian SME Sector. 